\title{
PERKEMBANGAN DAN PENINGGALAN DINASTI MOGHUL DI INDIA 1525-1857 \\ Supardi ${ }^{1}$
}

\section{Abstract}

There are three objectives to writing this article as follow, First is to know the background of the rise of Moghul Empire, Second to know growth and fall of the Moghul Empire, and the last several Moghul legacies such as in the aspect of politic, social, art, etc.

The founding father of Moghul Empire is Kutbu'ddin Aibak (1206-1211), who was able to establish Independence Islamic Kingdom of India. There are several ruler: Sultan Akbar, Syah Jahan, dan Aurangzib. Sultan Akbar has reputation as the ruler who was able to maintain stability of the empire as well as to combine the Islamic and Hindus civilization. Meanwhile Syah Jahan inherit some relics, such as the famous Taj Mahal.

Other ruler Aurangzib was to expand his empire. But the generation after Aurangzib fail to maintain unity of his empire and Moghul breakdown to several independence kingdom. The Sepoy Mutiny in 1857 is the end of Moghul Empire. British replace Moghul Empire and occupied whole India until 1947.

Keywords: Moghul Empire, Moghul inheritance, India.

\section{A. Pendahuluan}

India yang pada masa lalu meliputi negara India, Pakistan, dan Bangladesh pada masa sekarang selalu menarik dikaji. Ketiga negara ini memiliki kesinambungan sejarah yang satu hingga masa kolonialisme Barat. Secara geografis India terpisah oleh benteng alam pegunungan Himalaya di sebelah utara dan Hindu Kusy di sebelah Barat Laut. Pegunungan Himalaya merupakan benteng terpanjang yang membujur dari Afghanistan hingga Assam sejauh $2.500 \mathrm{~km}^{2}$. Kondisi geografis inilah sebagai salah satu penyebab sulitnya pengaruh luar masuk ke India. Walaupun begitu, berbagai bangsa silih berganti masuk ke daerah India dan memberikan warna perkembangan kebudayaan India terutama melalui celah Khyber yang menghubungkan dengan

${ }^{1}$ Dosen pada Jurusan Pendidikan Sejarah, Fakultas Ilmu Sosial dan Ekonomi, UNY.

${ }^{2}$ Abu Su'ud. 1988. Memahami Sejarah Bangsa-bangsa Asia Selatan Sejak Jaman Purba sampai Kedatangan Islam. Jakarta: Depdikbud PPLPTK. Hlm.10 
Afghanistan dan lintas Bolan yang di Pakistan. ${ }^{3}$. Setidaknya di India telah lahir 4 agama dunia yakni Hindu, Buddha, Jain, dan Sikh. Selain keempat tersebut, warna sejarah India juga dipengaruhi oleh pengaruh Islam yang berkembang pesat sejak pertengahan abad VII M dari jazirah Asia Barat.

Sejak awal abad XIII sampai dengan pertengahan XIX dinasti Islam berkembang di India. Masa pengaruh politik Islam telah dimulai sejak awal abad VIII ketika Muhammad bin al-Qasim diutus Khalifah al-Walid I menyerbu daerah Sind mulai tahun 708 M. ${ }^{4}$ Walaupun belum menguasai seluruh India, Qasim telah berhasil menancapkan pengaruh politik Islam di daerah Punjab. Sejak masa itu politik Islam terus merangsek di India. Dinasti Ghazni yang berkembang sejak tahun $961 \mathrm{M}$ berpusat di Afghanistan menjadi kekuatan politik kedua yang berpengaruh di India, dan dinasti Ghuri adalah pengaruh politik ketiga dalam sejarah kerajaan Islam di India. Akhir Dinasti Ghuri menandai mulainya kekaisaran Islam di India ditandai dengan berdirinya Kesultanan Delhi oleh Kutbu'ddin Aibak (1206-1211). Sejak saat itulah dinasti Islam berkembang di India sampai dengan tahun 1857.

Mengkaji kekuasaan para dinasti Islam di India sangat menarik, selain kekhasan sifat politik para dinasti Islam di India, juga akan ditemukan berbagai peninggalan kebudayaan yang luar biasa tinggi. Ada lima dinasti Islam yang berkuasa di India mulai tahun 1206-1857 M. Kelima Dinasti yang memerintah tersebut adalah ; Dinasti Budak (1206-1290), Dinasti Khilji (1290 - 1321), Dinasti Taghluk (1321 - 1388 ), Dinasti Lodhi (1450 - 1526), dan Dinasti Moghul (1526 1857). Berbagai peninggalan baik kebudayaan, sistem sosial, ekonomi, politik, hukum, dan pemerintahan masih dapat ditelusuri pada masa sekarang. Dinasti Moghul adalah dinasti terakhir yang memerintah di India. Bagaimana perkembangan dinasti Moghul dan pengaruhnya bagi sejarah peradaban bangsa India?

\section{B. Munculnya Kerajaan Moghul}

Peletak dasar dinasti Islam di India adalah Kutbu'ddin Aibak (1206-1211), yang berhasil mendirikan kerajaan Islam di India yang merdeka. ${ }^{5}$ Setelah

${ }^{3}$ Irwan Suhanda (ed.). 2007. India Bangkitnya Raksasa Baru Asia, Calon Pemain Utama Dunia di Era Globalisasi. Jakarta: Kompas.

${ }^{4}$ M Abdul Karim. 2003. Sejarah Islam di India . Yogyakarta: Bunga Grafies Production. Hlm. 12.

3 TSG Mulia. 1952. India Sejarah Politik dan Pergerakan Kebangsaan. Jakarta: Balai Pustaka. Hlm.40 
merasa cukup kuat untuk mendirikan kekuasaan di India, pada tahun 1206 ia mendirikan Kesultanan Delhi di India yang berhasil dipertahankan hingga 1290. Dinasti keturunan Aibak sering disebut dinasti keturunan hamba-hamba raja, karena Aibak sendiri bukanlah keturunan raja. Sultan Balban adalah raja terakhir dinasti keturunan hamba-hamba raja. Dia tidak meninggalkan keturunan dan pemerintahan Kesultanan Delhi selanjutnya diambil alih oleh dinasti raja-raja keturunan Khilji (1290-1321), kemudian dilanjutkan raja-raja keturunan Tughlak (1321-1399), dinasti para Sayid (1414-1451), dan dinasti rajaraja keturunan Lodi (1451-1526), kemudian yang terakhir adalah dinasti Dinasti Moghul.

Pergantian pemerintahan para raja yang berkuasa di Delhi tidak mulus begitu saja, tetapi sering terbentur pertumpahan darah dan saling menjatuhkan. Keturunan ketiga keluarga Lodi adalah Sultan Ibrahim Lodi (1517-1526) yang dianggap oleh beberapa pembesar kerajaan kurang cakap memerintah. Paman Ibrahim Lodi yang bernama Dhaulad Khan dan Alam Khan menjalin kerjasama dengan bangsa Mongol Sultan Babar dari Kabul (timur Afghanistan) untuk menjatuhkan Ibrahim Lodi. Kelompok Sultan Babur ini telah lama masuk Islam, dan mereka ahli dalam melakukan peperangan.

Sultan Babar/Babur adalah seorang keturunan bangsa Turki (pihak ayah) dan bangsa Padang Pasir Lodi/ Jengis Khan (pihak ibu). ${ }^{6}$ Sebagai seorang keturunan Mongol, Babar memiliki sifat bawaan pemberani dan ahli dalam perang. Ia berpandangan bahwa India akan berhasil dibangun menjadi imperium yang kuat mengingat kekayaan yang dimilikinya.

Pada saat Babur berkuasa di Kabul, situasi di India sedang dalam masa kekacauan pada masa pemerintahan Ibrahim Lodi. Kesempatan ini sebagai pintu bagi Babur untuk merealisasikan impiannya memperluas imperium sampai di India. Sultan Babur segera menyiapkan pertempuran untuk menjatuhkan raja Lodi. Pada tahun 1526 terjadi pertempuran besar di kota Panipat. Sultan Ibrahim Lodi dapat dikalahkan oleh tentara Sultan Babur, dan berakhirlah kerajaan Delhi. Sultan Babar kemudian mendirikan kerajaan Moghul dan pemerintahannya terkenal dengan nama kesultanan Moghul dengan ibu kotanya di kota Agra. Bagaimana perkembangan pemerintahan kerajaan Moghul selanjutnya?

${ }_{4}$ Tuti Nuriah Erwin. 1990. Asia Selatan dalam Sejarah. Jakarta : Lembaga Penerbit Universitas Indonesia. Hlm.37. 


\section{Perkembangan Politik Kerajaan Moghul}

\section{Pemerintahan Babur}

Kesultanan Moghul adalah Dinasti Islam yang terbesar dan terakhir di India. Setelah mengalahkan Ibrahim Lodi, Babur membangun stabilitas politik dan memperkuat angkatan perang serta melakukan penetrasi. Sampai tahun 1529 wilayah kekuasaan Moghul sangat luas mulai dari Turkestan sampai Teluk Bengala. Artinya daerah-daerah penting telah ada di bawah kekuasaan Moghul. Walaupun demikian Babur belum dapat dikatakan berhasil mengausai seluruh India.

\section{Pemerintahan Humayun}

Pada tahun 1530 Babur meninggal meninggalkan dua putra yakni Humayun dan Kamran. Humayun naik tahta menggantikan ayahnya dengan menghadapi berbagai persoalan gerakan desintegrasi dan ancaman usaha menjatuhkan kekuasaannya termasuk dari saudaranya sendiri. Waktunya lebih banyak untuk menyelesaikan masalah-masalah tersebut. Ancaman paling berat adalah dari Afghanistan. Kekuatan besar disiapkan untuk menghadapi Sher Khan (dari Afghanistan) yang berusaha merebut Agra. Humayun sempat menyingkir dari Agra, dan dengan bantuan Shah Thomas dari Persia Humayun berhasil menguasai Kabul kembali, kemudian Agra juga berhasil direbut tahun 1555. Humayun mempunyai putra bernama Akbar yang lahir semasa pelarian (1542). Pada tahun 1556 Akbar menggantikan Humayun yang kemudian terkenal sebagai sultan yang gagah berani dan memiliki prestasi tinggi.

\section{Pemantapan politik Sultan Akbar}

Sultan Akbar menghadapi persoalan kerajaan yang amat rumit. Dia berprinsip bahwa kekuatan negara terletak pada tentara dan administrasi ${ }^{7}$. Berbagai gerakan desintegrasi dan ancaman penjatuhan kekuasaan masih besar di depannya. Diantaranya adalah keponakan Sultan Sher Shah bernama Sultan Muhammad Adil Shah yang bekerjasama dengan panglima bangsa Hindu bernama Hemu. Tetapi kemudian Hemu justru melakukan perlawanan sendiri dengan menobatkan diri sebagai Vikramaditya (gelar Chandragupta II yang mashur pada abad IV M). Upaya penggulingan Sultan Akbar gagal, bahkan kemudian Delhi dapat direbut kembali dan perluasan kekuasaan terus dilakukan dengan gemilang. Pada tahun 1576 Rajputana, Gujarat, dan Bengala

5 ODP Sihombing. 1953. India, Sejarah dan Kebudayaannya. Bandung: W. Van Hoeve., hlm.70. 
telah berhasil dikuasai Sultan Akbar. Dengan demikian pintu barat dan timur melalui laut di India telah dikuasai Sultan Akbar.

Pada waktu naik tahta, Sultan Akbar baru berumur 13 tahun, sehingga kekuasaan kerajaan dipangku oleh wazir bernama Bairam Khan. Wazir ini pulalah yang menjadi guru Akbar sejak kecil sampai naik tahta. Setelah berusia 18 tahun, Akbar mulai melepas berbagai ketergantungan kepada orang lain. Upaya yang dilakukan Akbar adalah melepaskan diri dari berbagai orang, keluarga, dan bangsawan yang terlalu mempengaruhi dirinya. Akbar memiliki pemikiran ke depan untuk membangun India sebagai negara besar.

Prestasi politik gemilang Sultan Akbar adalah keberhasilannya mempersatukan berbagai daerah di India dalam kesultanan Moghul. Usaha ini bukan hal yang mudah, mengingat pada masa tersebut masih berkembang beberapa kerajaan Hindu dan Islam yang merdeka. Kegigihan dan kegagahan pasukan perang Akbar akhirnya berhasil menaklukan satu demi satu berbagai kerajaan di India. Kegemilangan penguasaan dimulai dalam mematahkan gerakan perlawanan bangsa Rajput yang tidak mau tunduk pada kekuasaan Moghul. Dikisahkan bahwa dalam menundukkan perlawanan tersebut pasukan Moghul membutuhkan waktu 7 bulan menggempur benteng Chitor di Udaipur. Kekalahan bangsa Rajput pada masa tersebut ditandai oleh kejadian dramatis. Sisa-sisa pasukan Rajput melakukan perlawanan puputan (habis-habisan). Orang tua, wanita, dan anak-anak melakukan bunuh diri setelah pasukan Rajput tidak lagi mampu membendung pasukan Moghul. Setidaknya 30000 korban tewas atau bunuh diri dalam pembasmian perlawanan bangsa Rajput.

Keberhasilan awal Sultan Akbar diikuti oleh kegemilangan terhadap perluasan kekuasaan selanjutnya. Tahun 1573 Gujarat berhasil dikuasai kemudian disusul Bengala tahun 1576. Akbar telah berhasil menguasai daerahdaerah penting India. Menjelang wafatnya tahun 1605, kekuasaan Moghul semakin mantap. Akbar juga melakukan akomodasi dengan masyarakat Hindu dengan melakukan berbagai kebijakan seperti penghapusan Jizya dan Djazia, pelarangan penyembelihan sapi, bahkan mengangkat beberapa orang Hindu untuk menduduki menteri-menteri dan pimpinan pasukan ${ }^{8}$.

\section{Sultan Jahangir (1605-1628)}

${ }^{6}$ Richard Symons. 1951. Pembinaan Pakistan. Jakarta: Balai Pustaka. 
Salim , putra Akbar dinobatkan sebagai raja Moghul dengan gelar Sultan Nurud'din Muhammad Jahangir Pasha Ghazi. Jahangir kontras dengan bapaknya dalam menegakkan pemerintahan Moghul terutama dalam menghadapi kelompok Hindu ${ }^{9}$. Dia menghadapi konflik luar biasa dengan anaknya sendiri, sampai kemudian meninggal tahun 1627 menyisakan konflik kerajaan. Kedua putranya bernama Shah Jahan dan Azaf Khan sama-sama berhasrat menggantikan ayahnya.

\section{Masa pemerintahan Sultan Shah Jahan (1628-1658)}

Shah Jahan akhirnya memenangkan persaingan untuk menggantikan Jahangir sebagai sultan Moghul. Pemerintahan masa Shah Jahan masih menghadapi berbagai gejolak dalam negeri dan ancaman perebutan kekuasaan dari negara-negara lain. Shah Jahan melanjutkan politik Sultan Akbar dengan melakukan penaklukan berbagai daerah untuk meredam pemberontakan dan memperluas kerajaan. Pada tahun 1636 dua kerajaan penting berhasil dikuasai yakni Ahmadnagar dan Bijabur ${ }^{10}$. Pada saat perluasan kekuasaan permaisurinya yang bernama Mumtaz-i-Mahal, istri yang amat dicintainya meninggal pada saat perang. Shah Jahan begitu kehilangan istri yang amat cantik dan dicintainya. Peninggalan makam dan masjid Tajmahal yang saat ini merupakan salah satu 7 keajaiban dunia merupakan tanda kasih Shah Jahan kepada istrinya.

Shah Jahan memiliki putra bernama Aurangzeb yang diberi kekuasaan di Decaan. Aurangzeb berhasil membuat stabilitas di Decaan terutama dalam menghadapi kekuatan kerajaan Hindu yang masih berusaha menolak kekuasaan Islam.. Persaingan paling kuat adalah antara Aurangzib dengan Dara Sikhoh. Dalam persaingan tersebut Aurangzib berhasil mengalahkan Dara Shikoh, dan mengambil alih kekuasaan Sultan Moghul tahun 1658. Sementara selama 7 tahun Shah Jahan menghabiskan waktunya di dalam benteng Agra hingga wafat menjemputnya. Shah Jahan, raja yang berambisius telah meninggalkan berbagai bangunan penting pada masa kesultanan Moghul yang menandai kebesaran kebudayaan kerajaan Moghul.

\section{Pemerintahan Aurangzib Alamgir dan upaya mengembalikan kebijakan jizya (1659-1707)}

Sultan Aurangzib Alamgir (penakluk dunia) dinobatkan di Delhi tahun 1659 segera melakukan kontrol keamanan dalam negeri dengan mamantapkan kembali kekuasaan di Decaan. Usahanya tidak sia-sia dengan semakin

${ }^{7}$ ODP Sihombing., Op .cit., hlm.72

8 TSG Mulia. Op. cit., hlm.53 
banyaknya wilayah yang dikuasai. Tahun 1685 kerajaan Bijabur tunduk, disusul Golkonda tahun 1687, Tanjore dan Trichinopoly tahun 1689. ${ }^{11}$ Aurangzib berhasil memperluas kekuasaan di India secara utuh melebihi daerah yang berhasil ditaklukan Sultan Akbar. Tinggal bangsa Maratha yang belum benarbenar bisa ditaklukan Aurangzib.

Perlawanan bangsa Maratha merupakan ancaman paling berat pada masa-masa selanjutnya. Sampai Aurangzib wafat tahun 1707 bangsa Maratha masih memberikan perlawanan sengit terhadap kesultanan Moghul. Tahun 1707 merupakan akhir pemerintahan Aungrazib yang tutup mata pada usia 90 tahun. Kekuasaan Aungrazib merupakan antiklimaks pemerintahan Moghul di India. Masa sesudahnya, kekuasaan Moghul terus mengalami kemunduran. Konflik saudara dari anak-anak Aungrazib menyebabkan kekuatan negara kian keropos. Apalagi pada masa pemerintahan Aungrazib, bangsa-bangsa Barat sudah giat melakukan perjalanan ke timur. Inggris adalah salah satu bangsa barat yang berhasil menduduki Surat, pelabuhan di Gujarat pada masa pemerintahan Aungrazib. Inilah cikal bakal kolonialisme dan imperialisme Barat di India yang akan mempengaruhi babak baru perjalanan sejarah bangsa India. Aungrazib menghidupkan kembali jizya yang pernah dicabut oleh Sultan Akbar, dan melakukan sikap keras terhadap orang-orang Hindu ${ }^{12}$.

\section{Dinasti Moghul pasca pemerintahan Aurangzib (1707-1857)}

Setelah meninggalnya Aurangzib situasi Dinasti Moghul semakin menunjukkan tanda-tanda keruntuhan, sementara kelompok Maratha justru menunjukkan kekuatannya baik dalam menggalang kekuatan maupun luas wilayah. ${ }^{13}$ Tiga keturunan Aungrazib yakni Muazzam, Azzam, dan Kambakhsh saling berselisih memperebutkan warisan dinasti kerajaan. Muazzam ternyata lebih kuat dan berhasil menobatkan diri sebagai penerus Moghul dengan gelar Sultan Bahadur Shah/Muhammad Syah (1707-1712 M). Kepemimpinan Sultan Bahadur Shah menghadapi keadaan kerajaan yang sulit untuk dikendalikan. Beberapa pemberontakan menggoyang eksistensi Moghul, termasuk

9 Ibid., hlm.59

10 Amal Hamzah.1952. Dunia Sekitar Kita, Pakistan Sebuah Negara Islam Muda. Jakarta: Djambatan. Hlm.19

11 Madjumdar, R.C., 1963. The Sepoy Mutiny and the Revolt of 1857, $2^{\text {th }}$ edition. Calcutta: Firma K.L. Mukhopadhyay. Hlm.1. 
pemberontakan kaum Sikh sebagai kelompok 'agama' baru yang merupakan sinkritisme Hindu dan Islam.

Secara politik sampai dengan keruntuhannya, kesultanan Moghul tinggal berusaha mempertahankan eksistensinya. Para sultan yang berkuasa tidak mampu menyatukan kerajaan. Kerajaan-kerajaan berusaha melepaskan diri dari kekuasaan Moghul. Konflik keluarga kerajaan terus memperlemah kekuasaan dan mendorong gerakan desintegrasi terus menjalar.

Sepeninggal Sultan Bahadur Shah (1712) terjadi perebutan kekuasaan oleh empat putranya. Jahamdar Shah berhasil naik tahta kerajaan selama 11 bulan, karena pada tahun 1713 ia dibunuh keponakannya bernama Farukhsiyar yang kemudian berhasil naik tahta hingga tahun 1719. Para sultan yang memerintah sampai dengan tahun 1761 adalah Sultan Muhammad Shah, Ahmad Shah, dan Alamgir II. Sementara kerajaan-kerajaan merdeka terus berdiri sendiri seperti Hydrabad, Quth, dan Bengala. Dengan begitu kekuataan kesultanan Moghul semakin lemah.

Bangsa Maratha adalah kelompok yang paling diuntungkan dengan situasi demikian. Mereka juga telah berhasil membangun kekuatan dan sistem pemerintahan yang lebih rapi. Sedikit-demi sedikit daerah yang dahulu dikuasai kesultanan Moghul direbutnya, seperti Gujarat dan Malwa. Pada tahun 1758 Punjab telah berhasil dikuasai Maratha, yang artinya Delhi sebagai pusat kekuasaan Moghul tinggal menunggu waktu saja.

Dalam keadaan yang semakin kacau, para raja Islam mulai sadar untuk melakukan persatuan melawan Maratha. Para raja Islam bersekutu dan meminta bantuan Sultan Ahmad Shah Durrani dari Afghanistan. Pada tahun 1760 Maratha telah menyerang Delhi dan terus bergerak ke utara. Pada tahun 1761 pecah pertempuran di dekat kota Panipat antara pasukan Maratha dengan pasukan gabungan kerajaan Islam India dan tentara Sultan Ahmad Shah Durrani.

Tentara Maratha tidak kuasa menghadapi gabungan tentara Islam yang sangat tangguh. Sebanyak 200.000 tentara Maratha tewas dari seluruhnya yang berjumlah 300.000. Perang tersebut merupakan klimaks perlawanan Maratha terhadap kerajaan Islam di India, karena mereka tidak lagi berani mengusik kekuasaan Moghul di India.

Keberhasilan menangkis perlawanan bangsa Maratha tidak serta merta membawa dinasti Moghul dalam kejayaan kembali. Kerajaan-kerajaan Islam yang semula bergabung melawan Maratha kembali melakukan rutinitasnya 
sebagai kerajaan yang berdiri sendiri. Tidak ada upaya nyata dalam menyatukan berbagai kerajaan tersebut. Dinasti Moghul tetap masih ada, tetapi layaknya sebagai macan ompong yang tidak lagi memiliki wibawa.

\section{Berbagai peninggalan Dinasti Moghul}

1. Sistem Politik dan Ekonomi.

a. India sebagai negara merdeka

Kebesaran dinasti Moghul tidak hanya ditunjukkan luasnya daerah yang disatukan dalam satu imperium, tetapi juga berbagai pembaharuan sistem politik. Apabila dicermati, penetrasi politik Islam pada masa sebelum dinasti Moghul masih memiliki ikatan kuat dengan dinasti Islam di Asia Barat. Dinasti Moghul dengan raja pertamanya Kutbu'ddin Aibak telah mendirikan dasar pemerintahan Islam secara merdeka di India, lepas dari kesultanan di Asia Barat. Hal ini sebagai hal yang unik mengingat wilayah Asia Selatan (India) bergandengan langsung dengan wilayah Asia Barat, walaupun secara geografis dipisahkan oleh pegunungan yang sulit dilalui. Sebagai sebuah negara, wilayah kesultanan Moghul mencapai wilayah terluas di India sepanjang sejarah sejajar dengan masa pemerintahan Ashoka. b. Pembagian wilayah kerajaan

Kerajaan Moghul memiliki pemerintah pusat yang beribukota di Delhi, sedangkan wilayah-wilayah di bawahnya identik dengan sistem propinsi dengan raja muda yang mengepalainya. Hal ini sebagai bentuk langsung pengaruh sistem pemeintahan Islam di Asia Barat. Gelar Sultan juga sebagai bentuk nyata pengaruh sistem politik Islam di Asia Barat. Walaupun secara politik kerajaan Moghul tidak memiliki ikatan secara langsung, tetapi hukum Islam yang diterapkan di berbagai kerajaan Islam memiliki peran kuat dalam sistem pemerintahan Moghul. Sebagai bentuk dinasti, kerajaan Moghul memiliki kelemahan seperti halnya sistem kedinastian lain. Dalam kerajaan berbentuk dinasti, penguasa tertinggi dilakukan turun-temurun. Akibatnya keadaan kerajaan sangat tergantung pada kecakapan seorang raja dalam memerintah. Hal ini dapat dilihat dalam perjalanan sejarah kerajaan Moghul. Sultan Akabar dapat dinilai sebagai raja yang cakap dalam memantapkan stabilitas pemerintahan dan melakukan akomodasi berbagai kekuatan politik yang menyebabkan perpecahan.

c. Sumber pendapatan negara 
Pajak merupakan salah satu sumber utama keuangan kerajaan. Pada masa pemerintahan Islam di India jizya diterapkan sejak pemerintahan Dinasti Taghluk (1321 - 1388). Jizya adalah pajak kepala untuk orang-orang non muslim. Sementara untuk orang Islam zakat merupakan bentuk pajak menurut syariat Islam. Dengan demikian pada dasarnya baik muslim maupun non muslim memiliki tanggungjawab sama dalam masalah pajak. Kaum non muslim tetap mendapat perlindungan dari kerajaan dalam melaksanakan aktivitas sehari-hari maupun dalam menjalankan ibadahnya. Pada masa Sultan Akbar, jizya ini dihapuskan dan digantikan dengan pajak tanah. Dengan dibantu seorang Hindu bernama Raja Todar Mall Sultan Akbar menerapkan pajak tanah yang nilainya disesuaikan dengan tingkat kesuburan dan luas tanah ${ }^{14}$. Pada masa Aurangzib jizya kembali diberlakukan.

2. Perubahan Sosial

Semenjak Islam masuk ke India, pengaruh mendasar yang utama adalah masalah penghapusan kasta yang telah mendarah daging ratusan tahun lamanya. Islam tidak mengenal kasta, sehingga oleh sebagian masyarakat Islam di India terutama pada kasta rendah, kedatangan Islam disambut dengan senang hati. Dampaknya adalah terjadinya transformasi sosial karena kesetaraan penduduk dalam memperoleh akses ekonomi dan untuk bagian tertentu adalah menjadi pegawai pemerintah dan tentara.

Perubahan menonjol lainnya adalah masalah kesetaraan gender. Keberadaan kaum wanita yang selama ratusan tahun menjadi kelompok kelas dua terangkat oleh masuknya Islam di India. Upacara Sati (menceburkan diri ke api seorang perempuan dalam pembakaran mayat suaminya) terus terkikis oleh pengaruh Islam di India. Namun demikian bukan berarti upacara Sati ini terhapus begitu saja di India. Sampai dengan abad XX upacara Sati masih dilakukan oleh sebagian masyarakat India.

Kedatangan Islam di India memang menjadi pencerahan bagi kaum lemah seperti yang diungkapkan Hunter dalam Rychard Symonds ${ }^{15}$;

Bagi orang-orang melarat ini nelajan-nelajan, pemburu-pemburu, perompakperompak dan pembadjak-pembadjak tanah, dari kasta rendah, Islam datang sebagai kurnia dari langit. Ia merupakan kepercayaan dari kaum yang memerintah ...."

\footnotetext{
${ }^{14}$ TSG Mulia. Op.cit.,hlm.48.

${ }^{15}$ Rychard Symonds. Op.cit., hlm.19
} 
Kisah yang cukup menarik adalah munculnya empat ratu (raja perempuan) di kerajaan Bhopal yang melepaskan diri dari Mohul abad XIX. Salah satu dari keempat ratu tersebut adalah Syahjihan Begum (1868-1901) yang menikah dengan seorang ulama besar Maulvi Sayid Muhammad Shadieq Hasan Kan. ${ }^{16}$

Tidak bisa dipungkiri bahwa pengaruh Islam di India telah mengangkat jutaan kaum tertindas dari kasta rendah. Namun di sisi lain kedatangan Islam menyebabkan kemunduran kebudayaan Hindu yang telah berlangsung berabad-abad sebelum Masehi. Bahkan beberapa sikap raja Muslim kadang menyakitkan sebagian masyarakat Hindu. Hal ini tentu bukan disebabkan oleh ajaran Islam itu sendiri, tetapi oleh sikap dan karakter individu raja tersebut. Sebagai contoh adalah kebijakan yang dilakukan Aurangzib dalam memperlakukan masyarakat Hindu. Misalnya ia melarang pembangunan kuil-kuil untuk orang Hindu dan pemberlakuan pajak lebih berat pada masyarakat Hindu. ${ }^{17}$ Hal ini sebagai salah satu penyebab semakin memudarnya kewibawaan kesultanan Moghul.

\section{Seni dan Bangunan}

\section{a. Karya Sastra}

Berbagai karya sastra banyak muncul di India pada masa Dinasti Moghul. Dalam syariat Islam tidak ada pemisahan antara politik dan ibadah, antara imam dan pemimpin pemerintahan. Tiap sendi kehidupan manusia terintegrasi dalam nilai-nilai agama. Pemimpin kerajaan bukan sekedar melaksanakan roda pemerintahan, tetapi sekaligus sebagai imam yang berpengetahuan keagamaan tinggi dan pantas diteladani. Tidak heran bila karya seni dan sastra yang muncul tidak sebatas ditulis para ulama, tetapi juga para raja.

Pada masa raja Akbar riwayat dan pemikiran Sultan Akbar ditulis oleh filosof Abul Fazl dengan judul A'ini Akbari dan Akbar-nama. Dua kitab tersebut ditulis dalam bahasa Persi dan kini juga telah diterjemahkan dalam Bahasa Inggris. Akbar adalah sosok pemimpin yang berusaha menyatukan dua kekuatan penting di India yakni Islam dan Hindu. Maka beliau terkenal dengan ajarannya Din-Illahi yang hendak dijadikan agama kerajaan. Beliau

${ }^{16}$ H Zainal Abidin Ahmad. 1979. Ilmu Politik Islam V. Sejarah Islam dan Umatnya Sampai Sekarang (Perkembangannya dari zaman ke zaman). Jakarta: Bulan Bintang.

17 Tuti Nuriah Erwin, Op. cit., hlm. 42. 
juga mengambil permaisuri seorang Hindu sehingga sebagian ada yang menyangsikan kehidupan Islam Sultan Akbar. Toleransinya sangat dikenal bahkan memberi kebebasan para misionaris Barat untuk menyebarkan agama Kristen di India.

Raja Jahangir juga meninggalkan karysa satra dengan menulis riwayat hidupnya dalam kitab Tzuk-i-Jahangiri. Abdul Hamid Lahori, seorang sejarawan pada masa Shah Jahan menulis riwayat hidup Shah Jahan dalam kitab Padchah Nama.

\section{b. Bangunan}

Sultan Akbar tidak hanya terkenal sebagai raja yang disegani karena keberaniannya dalam peperangan. Pemerintahan beliau juga meninggalkan berbagai bangunan penting seperti bangunan masjid dan istana di kota Agra.

Pada tahun 1636 Sultan Shah Jahan berhasil menguasai dua kerajaan penting berhasil dikuasai yakni Ahmadnagar dan Bijabur. Pada saat perluasan kekuasaan tersebut permaisurinya Mumtaz-i-Mahal meninggal tahun 1631. Begitu cintanya pada istrinya, Shah Jahan mengenangnya dengan membuat mega proyek makam Mumtaz Mahal yang artinya mutiara istana yang dibangun tahun 1631-1648 dengan melibatkan 20.000 pekerja ${ }^{18}$. Bangunan makam tersebut dilengkapi dengan masjid dan taman dengan arsitek tinggi. Kemashurannya sampai di penjuru benua, dan saat ini merupakan salah satu keajaiban dunia.

Shah Jahan juga telah membuat rencana bangunan makam untuk dirinya yang rencananya tidak kalah indahnya dengan Mumtaz Mahal. Tetapi wasiat itu tidak dilaksanakan penggantinya Aurangzib yang tidak menyukai kemegahan bangunan. Jenazah Shah Jahan dimakamkan berdampingan dengan istri tercintanya Mumtaz Mahal.

Shah Jahan juga meninggalkan berbagai bangunan indah dan megah lainnya seperti Masjid Ja'mi, Istana Shah Jahanabad, Masjid Mutiara di Agra, Dewan di Delhi, Agra, dan Lahore merupakan kekhasan bangunan dengan kreasi tinggi perpaduan arsitek Persia dan India. Aurangzib, walaupun tidak meninggalkan bangunan sebesar masa Shah Jahan, tetapi juga membangun masjid Badshahi di Lahor dan Pearl Mosque di Delhi, walaupun kecil tetapi berninai arsitek tinggi dan kemewahan bangunan. ${ }^{19}$

18 Ruslan dan Feby Nurhayati. 2007. Di Balik Pesona Tujuh Keajaiban (Baru) Dunia. Yogyakarta: Ombak.

${ }^{19}$ http://www.indialife.com/history/themughal, diakses tanggal 12 Oktober 2008 
4. Perkembangan kepercayaan dan aliran keagamaan

Masuknya Islam di India bukan tidak menimbulkan masalah konflik kepercayaan. Hal ini sangat wajar mengingat di wilayah tersebut berkembang dua agama besar terutama Hindu dan Islam. Sikap para penguasa Islam yang berusaha membuat keadilan dalam menjalankan ibadah kadang sulit dilakukan oleh munculnya berbagai kecurigaan dan kesalahpahaman politik. Upaya melakukan akomodasi kedua agama ini pernah dilakukan oleh Sultan Akbar dengan melahirkan ajaran baru Din Illahi tahun $1582^{20}$, namun tidak mendapat respon positif dari para ulama Islam. Akbar juga memperistri seorang Hindu dengan maksud menghilangkan pertentangan dua pemeluk agama terbesar di India tersebut.

Islam dan Hindu yang kadang memunculkan pertentangan tersebut kemudian mendorong munculnya aliran kepercayaan baru yang kemudian berkembang menjadi salah satu agama besar di India. Pada abad XV muncul agama Sikh yang merupakan sinkritisme Islam dan Hindu dengan pemimpinnya yang terkenal dengan sebutan Guru Nanak (1469-1539). Sikh (artinya murid) terus berkembang, dan guru Nanak laksana sebagai Rasul yang kemudian dilanjutkan oleh guru-guru selanjutnya sampai guru ke sepuluh yakni Guru Govind Singh (1675-1708). Agama Sikh terus berkembang dan mendapat tentangan baik umat Islam maupun Hindu. Lambat laun penganut Sikh membuat kelompok tersendiri dan berhasil membangun kekuatan baru di Asia Selatan.

\section{E. Indian Mutiny 1857 dan Runtuhnya Dinasti Moghul}

Masuknya bangsa-bangsa Barat ke India telah menambah konflik semakin rumit untuk diselesaikan Dinasti Moghul. Inggris berhasil membuka pintu timur, yakni di Selat Benggala, ditandai pada tahun 1764 Gubernur Benggala sebagai pintu masuk India ditundukkan Inggris yang. Sejak saat itulah penetrasi bangsa Barat semakin merangsek ke berbagai pelosok India. Walaupun demikian, secara formal keberadaan Dinasti Moghul masih ada hingga tahun 1857, ketika Sultan Bahadur Shah yang berkuasa masa tersebut dijadikan simbol perlawanan/pemberontakan terhadap Inggris yang terkenal

${ }^{20}$ Schulberg, Lucille (ed.). 1983. India yang Bersejarah, terj.Tira Pustaka, ( judul asli: Historic India). Jakarta: Tira Pustaka. Hlm.162. 
dengan nama "Pemberontakan Sepoy, Sepoy Mutiny, atau The First War of India Independence".

\section{F. Kesimpulan}

Peletak dasar dinasti Islam di India adalah Kutbu'ddin Aibak (12061211), yang berhasil mendirikan kerajaan Islam di India yang merdeka. Raja-raja terbesar dari dinasti Moghul adalah Sultan Akbar, Sultan Shah Jahan, dan Sultan Aurangzib. Sultan Akbar terkenal sebagai raja yang berusaha melakukan akomodasi politik dan kultur atas kekuasaan Islam dan masyarakat Hindu di India. Di bawah kepemimpinannya Moghul berhasil berkembang menjadi dinasti yang besar. Sultan Shah Jahan terkenal dengan peninggalannya dalam seni dan bangunan. Makam Tajmahal sebagai salah satu dari tujuh keajaiban dunia saat ini merupakan salah satu bangunan peninggalan masa pemerintahannya. Sementara Sultan Aurangzib sebagai pemimpin yang berhasil mengembangkan kekuasaan Dinasti Moghul sehingga memiliki wilayah kekuasaan yang sangat luas.

Generasi sesudah Aurangzib gagal membangun kesatuan kerajaan, hingga akhirnya Mogul terpecah menjadi beberapa kerajaan yang berdiri sendiri. Bersamaan melemahnya Moghul, bangsa-bangsa Barat terus melakukan penetrasi di India. Akhirnya Inggris berhasil menjadi negara yang paling berkuasa di India hingga tahun 1947. Pemberontakan Serdadu India/Sepoy Mutiny/India Mutiny yang gagal menandai berakhirnya Dinasti Moghul. Sultan Bahadurshah diasingkan ke Birma, dan kesultanan Moghul dihapus, pemerintahan di India diambil alih oleh Inggris.

\section{DAFTAR PUSTAKA}

Abu Su'ud. 1988. Memahami Sejarah Bangsa-bangsa Asia Selatan Sejak Jaman Purba sampai Kedatangan Islam. Jakarta: Depdikbud PPLPTK.

Amal Hamzah.1952. Dunia Sekitar Kita, Pakistan Sebuah Negara Islam Muda. Jakarta: Djambatan.

H Zainal Abidin Ahmad. 1979.Ilmu Politik Islam V. Sejarah Islam dan Umatnya Sampai Sekarang (Perkembangannya dari zaman ke zaman. Jakarta: Bulan Bintang.

Irwan Suhanda (ed.). 2007. India Bangkitnya Raksasa Baru Asia, Calon Pemain Utama Dunia di Era Globalisasi. Jakarta: Kompas 
Madjumdar, R.C., 1963. The Sepoy Mutiny and the Revolt of 1857, 2th edition. Calcutta: Firma K.L. Mukhopadhyay.

M Abdul Karim. 2003. Sejarah Islam di India. Yogyakarta: Bunga Grafies Production.

ODP Sihombing. 1953. India, Sejarah dan Kebudayaannya. Bandung: W. Van Hoeve.,

Richard Symons. 1951. Pembinaan Pakistan. Jakarta: Balai Pustaka

Schulberg, Lucille (ed.). 1983. India yang Bersejarah, terj.Tira Pustaka, judul asli:Historic India. Jakarta:Tira Pustaka.

TSG Mulia. 1952. India Sejarah Politik dan Pergerakan Kebangsaan.Jakarta: Balai Pustaka.

Tuti Nuriah Erwin. 1990. Asia Selatan dalam Sejarah. Jakarta : Lembaga Penerbit Universitas Indonesia.

Internet :

"Ancient India: The Mughal, an Introduction to the Mughal Dynasty and Mughal Agra" dalam http://www.indialife.com/history/themughal, diakses tanggal 12 Oktober 2008

\section{Tentang Penulis:}

\section{Supardi}

Menyelesaikan pendidikan S1 dari Jurusan Pendidikan Sejarah FPIPS IKIP Yogyakarta pada tahun 1997. Sementara S2 pada Program Studi PIPS Universitas Negeri Yogyakarta diselesaikan pada tahun 2007. Kegiatan akademik yang dilakukan antara lain: seminar, menulis, dan membimbing mahasiswa. Saat ini mengampu mata kuliah: Sejarah Asia Selatan, Strategi Pembelajaran Sejarah dan Pendidikan IPS. 


\section{PEDOMAN PENULISAN NASKAH \\ JURNAL ISTORIA}

1. Redaksi menerima naskah berupa hasil pemikiran, analisis ilmiah, kajian teori, maupun hasil penelitian bidang sejarah dan pendidikan sejarah.

2. Naskah dapat disajikan dalam bahasa Indonesia maupun bahasa Inggris.

3. Naskah belum pernah diterbitkan oleh media lain, baik media cetak maupun elektronik.

4. Panjang tulisan berkisar antara 10-25 halaman dalam kertas ukuran A4 dengan spasi ganda.

5. Naskah harus disertai dengan abstrak dalam bahasa Inggris, bila naskah ditulis dalam bahasa Indinesia, dan dalam bahasa Indonesia bila naskah ditulis dalam bahasa Inggris. Abstrak disertai dengan kata kunci yang merupakan variabel dalam naskah.

6. Sistematika penulisan sebagai berikut:
a. Judul
b. Abstrak disertai kata kunci
c. Pendahuluan
d. Isi atau pembahasan
e. Penutup dan simpulan
f. Daftar pustaka
g. Biodata penulis

7. Penulisan referensi menggunakan catatan kaki (foot note).

8. Redaksi berhak mengedit tata bahasa maupun naskah yang dimuat tanpa mengurangi maksud dan tujuan tulisan.

9. Isi tulisan merupakan tanggung jawab penulis sepenuhnya. 
10. Naskah dikirim kepada redaksi Istoria rangkap 2 dalam format print out yang disertai soft copy dala format $\mathrm{CD}$, disket, atau media lainnya.

11. Kepada penulis yang naskahnya dimuat akan diberikan 2 eksemplar jurnal sebagai bukti.

12. Naskah yang tidak dimuat dikembalikan kecuali disertai dengan perangko secukupnya.

13. Naskah dikirimkan kepada redaksi paling lambat 2 bulan sebelum penerbitan. 